Krzysztof BLACHA, Mariusz WESOŁOWSKI

Air Force Institute of Technology (Instytut Techniczny Wojsk Lotniczych)

\title{
SKID RESISTANCE PROPERTIES OF AIRFIELD PAVEMENTS IN THE LIGHT OF APPLICABLE NORMATIVE RULES
}

\section{Właściwości przeciwpoślizgowe nawierzchni lotniskowych w aspekcie obowiązujących przepisów normatywnych}

\begin{abstract}
Skid resistance properties of airfield pavements substantially affect the safety of the conducted aircraft operations. The evaluation of these properties is not limited to the measurements of friction coefficient defining the friction state of pavement, but also includes the measurements of texture depth of pavement (micro- and macro-texture). The authors focused on the currently applied research methods used to assess the skid resistance properties of airfield pavements. In addition, the requirements in this field and the assessment criteria of the obtained results were also addressed. Example results of field tests and their short analysis were also presented. Besides, it was stressed the direction of further works conducted by the authors, which concerns the development of the research method used to assess the skid resistance properties of airfield pavements, precisely in the field of the measurement of texture depth of pavements.
\end{abstract}

Keywords: airfield pavement, surface texture, roughness, skid resistance properties

Streszczenie: Właściwości przeciwpoślizgowe nawierzchni lotniskowych $w$ istotny sposób wpływaja na bezpieczeństwo wykonywania operacji lotniczych. Ocena tych właściwości oprócz pomiarów wspótczynnika tarcia określajacego stan szorstkości nawierzchni obejmuje również pomiary głębokości tekstury nawierzchni (mikrotekstura i makrotekstura). $W$ artykule przedstawiono obecnie stosowane metody badawcze do oceny właściwości przeciwpoślizgowych nawierzchni lotniskowych. Zaprezentowano przykładowe wyniki badań terenowych $i$ ich analize. Ponadto, przedstawiono kierunek dalszych prac, które dotycza rozwoju metody badawczej do oceny właściwości przeciwpoślizgowych nawierzchni lotniskowych, konkretnie w zakresie pomiaru głębokości tekstury nawierzchni.

Słowa kluczowe: nawierzchnia lotniskowa, tekstura nawierzchni, szorstkość, właściwości przeciwpoślizgowe 


\section{Introduction}

The technical condition of airfield pavements impacts the safety of performed aircraft operations. Skid resistance properties are one of the elements used to estimate the health of pavements. They describe the adhesion of the aircraft's tyre to the pavement, that is the ability to produce friction force between airfield functional element (EFL) and aircraft's wheels during the mutual slide.

The primary parameter which has crucial importance in determining the condition of airfield pavement in the area of skid resistance properties is a friction coefficient, defined as a dimensionless relation of friction force between two bodies to the normal pressure force of these two bodies [11].

$$
\mu=\frac{T}{N}
$$

where:

$\mu-$ friction coefficient,

$T$ - horizontal friction force by braking the wheel [N],

$N$ - vertical reaction of the surface to the wheel load [N].

It is a parameter determining the correct trajectory of a moving aircraft at the aerodrome's manoeuvering field. The applied braking systems will not work if the aircraft's wheel is not of the proper adhesion to the surface. Then, there are reported the aircraft incidents associated with falling the aircraft out of the runway caused by the loss of adhesion. These situations force designers to consider the obtained skid resistance parameters of the surface already at the design stage.

In practice, it is intended that after touchdown the aircraft moves with a retarded motion, which signifies that the braking forces will be balanced by the friction force. In a situation when the braking force exceeds the friction force, the wheel starts to slide across the surface, which results in the pilot's partial or full loss of control of the aircraft. During slamming on the brakes, the brakes produce a braking torque $\left(M_{\mathrm{H}}\right)$ which is transferred to the circumference of a circle, and it thus leads to the creation of braking force between the tyre and the surface (fig. 1). 


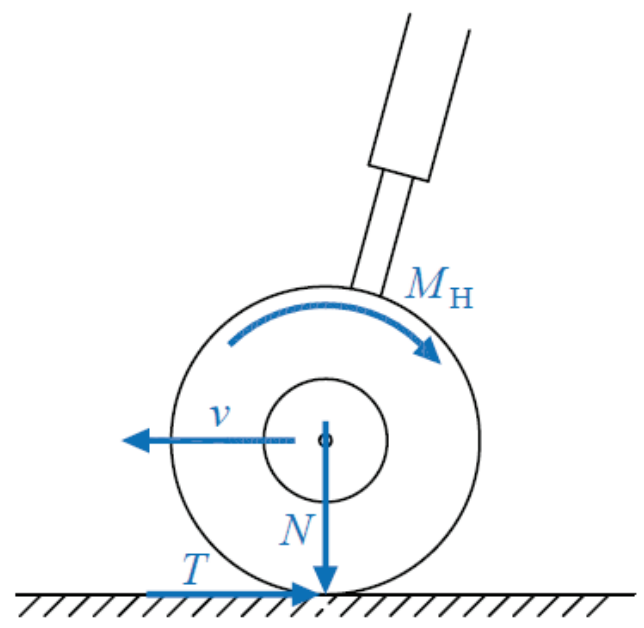

Fig. 1. Diagram of forces acting on the braking wheel: $M_{\mathrm{H}}-$ braking torque produced by brakes, $T$ - friction force compensating the braking force, $N$ - pressure force of wheel, $v$ - speed of the centre of the wheel in the longitudinal direction

The second component of the characteristics of pavement/tyre friction is a pavement texture (micro-and macro-texture). Elaborating on the pavement microtexture, the roughness of waves with a length not smaller than $0.5 \mathrm{~mm}$ (texture with a depth of $0.5 \mathrm{~mm}$ ) was addressed. However, the macro-texture relates to the roughness of pavement with wavelengths of $0,5-50 \mathrm{~mm}$ (texture depth above $0,5 \mathrm{~mm})[2,7,10]$.

The micro-texture is defined as a texture of individual stones (aggregate particles), and it is difficult to observe it with the naked eye. It may change over a short period of time without even being noticed. The assessment of micro-texture is made directly based on the polished stone index $P S V$ [9], which is a value obtained due to the measurement of friction in adherence to international standards. These standards define the $P S V$ minima enabling to select the material with good micro-texture [12].

The macro-texture is defined as texture between individual stones (aggregate particles) and facilitates the drainage of water from pavement/tyre interface, especially by high speeds. It is created mainly by the size of used aggregate or by the treatment of the surface. If the surface has a good macro-texture enabling to remove the water from the tyre, then the friction will be affected by speed to a smaller extent. Not to mention that by the worse macro-texture will be detected an increased decline in the value of friction by the increasing speed. 


\section{Assessment methods of skid resistance properties}

Both roughness, as well as the texture of airfield pavements, belong to the features denoting its skid resistance properties; which means that they are checked with the same purpose. It has to be mentioned that in situ measurement methods applied to determine these parameters, i.e. the coefficient of friction and texture depth, differ from each other. Currently, the roughness of airfield pavements is investigated by employing the method based on continuous measurement and texture depth is examined with methods based on spot measurements.

\subsection{The roughness of airfield pavements}

Measurements of the friction coefficient of airfield pavements are done in compliance with the Polish Defence Standard NO-17-A501:2015 Nawierzchnie lotniskowe. Badanie szorstkości [5] (NO-17-A501:2015 Airfield pavements Roughness testing [5]), developed based on foreign documents [13,1,4].

The aforementioned standard contains the list of devices approved for the roughness assessment of airfield pavements, which enable the continuous measurement of friction coefficient, reflecting the interaction between aircraft's wheel and airfield pavement (table 1). Besides, such device shall comply with the requirements of the test tyre and sprinkler system. The detailed parameters of a test tyre including the type of tyre and its corresponding pressure values are included in document [4]. It is permitted to also use other measuring devices than mentioned in the standard, which should also be subject to test procedure [4].

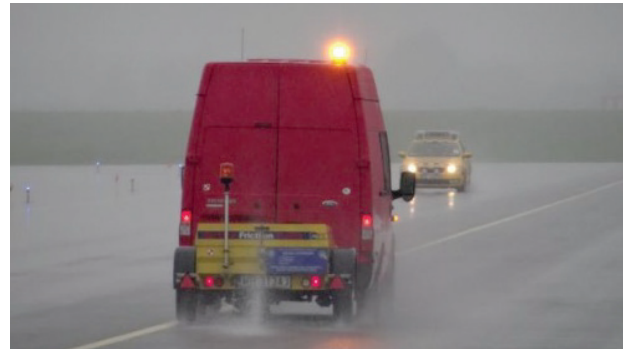

(a)

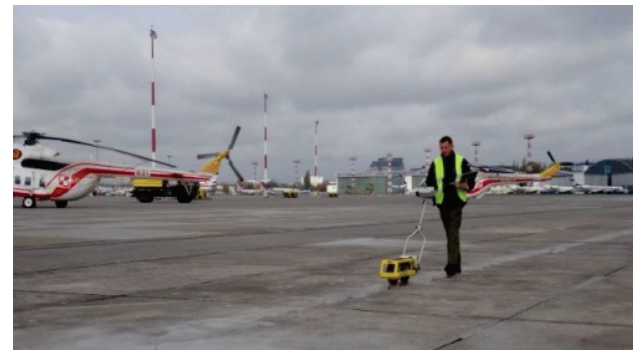

(b)

Fig. 2. Airport surface friction tester (ADFT) on T-10 trailer (a); manual, portable, air port surface friction measuring equipment T2Go (b) [source: archive of AFIT]

The most common devices applied to measure the friction coefficient at Polish airfields are testers from ASFT company, which are mounted on the trailer (fig. 2a) or on the autonomous vehicle. These devices enable continuous, linear 
measurement of the friction coefficient between airfield pavement and standard aircraft wheel, with test speed of 65 or $95 \mathrm{~km} / \mathrm{h}$. They are equipped with a water tank and a self-wetting system delivering water under the test wheel to achieve the water film required by standards with the thickness not smaller than $1 \mathrm{~mm}$.

Smaller airfield functional elements (EFL), whose geometrical dimensions prevent the measurement by the speed of 65 or $95 \mathrm{~km} / \mathrm{h}$, can be investigated by using a manual roughness tester T2Go (fig. 2b) or - more rarely - BVS-1 device. T2Go friction tester allows the continuous measurement of friction coefficient by low speeds and the cooperation between the tester as mentioned above and the ASFT friction tester on a T-10 trailer enables to refer to the requirements included in the aforesaid documents.

\subsection{Texture of airfield pavements}

The assessment of texture of airfield pavements is currently done with volumetric method (measurement of the mean texture depth-MTD) in conformity with PN-EN 13036-1:2010 Cechy powierzchniowe nawierzchni drogowych i lotniskowych. Metody badań. Część 1: Pomiar głębokości makrotekstury metoda objętościowa [6] (PN-EN 13036-1:2010 Surface properties of road and airfield pavement. Research methods. Part 1: Measurement of depth of macrotexture with volumetric method) or profilometric method (measurement of mean profile depthMPD) according to PN-EN ISO 13473-1:2005 Charakterystyka struktury nawierzchni przy użyciu profili powierzchniowych. Część 1: Określenie średniego profilu głębokości [7]. (PN-EN ISO 13473-1:2005 Characteristics of pavement structure using surface profiles. Part 1: Determining the mean profile depth).

The volumetric method, also called the calibrated sand method (or sand path method) is since many years commonly applied across the world to measure pavement texture and was described in detail in ICAO (International Civil Aviation Organization) [4] and FAA (Federal Aviation Administration) [1] documents.

The range of the applied method is in between $0,25 \mathrm{~mm}$ to $5 \mathrm{~mm} \mathrm{MTD}$. It consists in spreading of a known volume of granular material (usually sand or glass beads) in a circular motion on the examined surface. The measurement is done with the use of the glass beads, from which almost $90 \%$ pass the $0.25 \mathrm{~mm}$ sieve and retained on the $0.18 \mathrm{~mm}$ sieve. The material is distributed on the surface with the use of a hard rubber disc with a diameter of $65 \mathrm{~mm}$ and depth of approx. $25 \mathrm{~mm}$. The measured value is the average diameter of the created patch (fig. 3). 


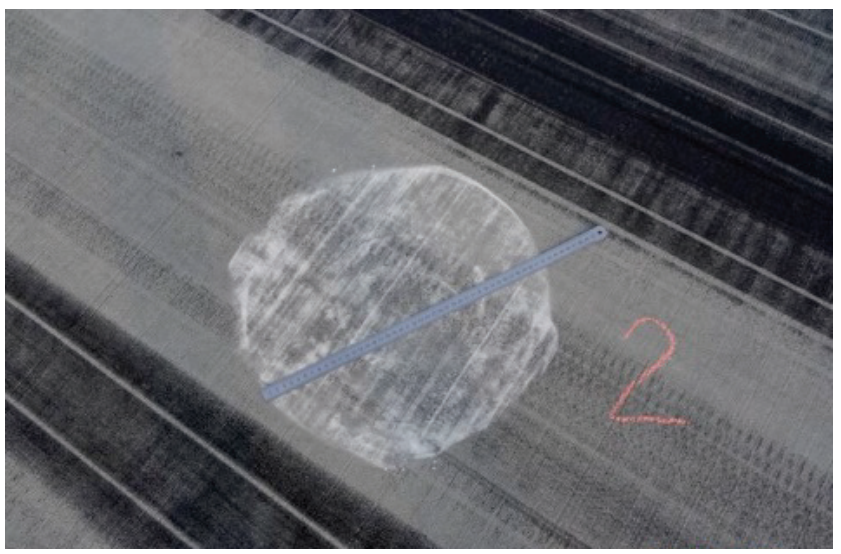

Fig. 3. The view of the created patch [source: archive of AFIT]

The result of the test is the mean texture depth obtained from the formula:

$$
M T D=\frac{4 V}{\pi D^{2}}
$$

where:

$M T D$ - mean texture depth [mm],

$V \quad$ - sample volume of granular material $\left[\mathrm{mm}^{3}\right]$,

D - diameter of the circle covered with granular material [mm].

The sample volume of granular material is calculated from the following equation:

$$
V=\frac{\pi d^{2} h}{4}
$$

where:

$d-$ internal diameter of the container filled with granular material [mm],

$h$ - height of container filled with granular material [mm].

The profilometric method assumes the measurement of the profile of the pavement surface with a laser sensor with a high sampling frequency (measuring devices are called profilographs or profilometers). By utilising this method, we obtain a pavement profile, which is subject to further analysis and the so-called mean profile depth $(M P D)$ is determined. The profile presents the surface in two 
dimensions and is described by two coordinates: distance (along pavement surface) and amplitude (perpendicular to pavement surface). The profilometric method can be applied with $M P D$ ranging from $0 \mathrm{~mm}$ to $5 \mathrm{~mm}$, and a threshold value between micro- and macro-texture is $0.5 \mathrm{~mm}$.

$M P D$ can be converted in estimated texture depth ETD. To this end, the transformation equation shall be used:

$$
E T D=0,2+0,8 M P D
$$

The resultant $E T D$ value shall be as close to the $M T D$ value as possible.

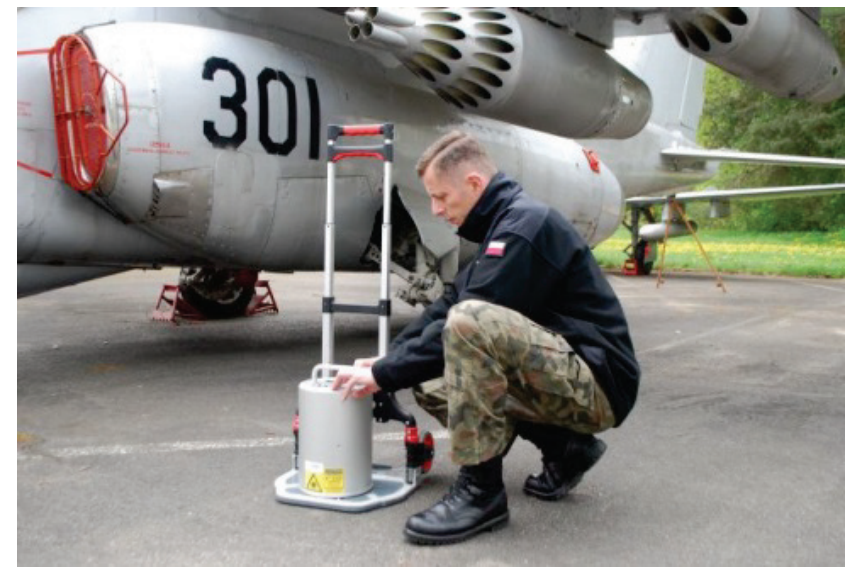

Fig. 4. Device ELATextur for the measurement of macrotexture [source: archive of AFIT]

\section{Requirements concerning skid resistance properties}

Both the roughness and texture of airfield pavements are features tested for the same purpose, and it may seem that the requirements in this field will be interrelated. In reality, it looks a bit different.

\subsection{Requirements concerning roughness of airfield pavements}

Requirements in the area of the value of friction coefficient for airfield pavements are demonstrated in many international documents $[13,1,4]$ and the Polish defence standard [5]. These documents include the values of friction coefficients, which shall be obtained on EFL surfaces to enable air operations by the conformance of safety and dependability of aircraft (table 1). 
Table 1

Requirements according to NO-17-A501:2015 Nawierzchnie lotniskowe - Badanie szorstkości (Airfield pavements - Roughness testing) [5]

\begin{tabular}{|c|c|c|c|c|c|c|c|}
\hline \multirow[b]{2}{*}{$\begin{array}{l}\text { Measuring } \\
\text { devices }\end{array}$} & \multicolumn{2}{|c|}{ Test tyre } & \multirow[b]{2}{*}{$\begin{array}{c}\text { Test } \\
\text { speed } \\
{[\mathbf{k m} / \mathbf{h}]}\end{array}$} & \multirow[b]{2}{*}{$\begin{array}{c}\text { Thickness } \\
\text { of water } \\
\text { film } \\
{[\mathrm{mm}]}\end{array}$} & \multicolumn{3}{|c|}{ Friction coefficient } \\
\hline & $\stackrel{2}{2}$ & 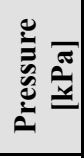 & & & $\begin{array}{c}\text { Design } \\
\text { values for } \\
\text { new } \\
\text { pavements }\end{array}$ & $\begin{array}{c}\text { Values for } \\
\text { planning } \\
\text { corrective } \\
\text { actions }\end{array}$ & $\begin{array}{l}\text { Minimum } \\
\text { values } \\
\text { (threshold) }\end{array}$ \\
\hline \multirow{2}{*}{ ASFT trailer } & B & 700 & 65 & 1.0 & 0.70 & 0.50 & 0.40 \\
\hline & $\mathrm{B}$ & 700 & 95 & 1.0 & 0.60 & 0.40 & 0.32 \\
\hline \multirow{2}{*}{$\begin{array}{l}\text { Mu-meter } \\
\text { trailer }\end{array}$} & A & 70 & 65 & 1.0 & 0.72 & 0.52 & 0.42 \\
\hline & A & 70 & 95 & 1.0 & 0.66 & 0.38 & 0.26 \\
\hline \multirow{2}{*}{$\begin{array}{l}\text { Skiddometer } \\
\text { trailer }\end{array}$} & B & 210 & 65 & 1.0 & 0.82 & 0.60 & 0.50 \\
\hline & $\mathrm{B}$ & 210 & 95 & 1.0 & 0.74 & 0.47 & 0.34 \\
\hline \multirow{2}{*}{$\begin{array}{c}\text { RUNAR } \\
\text { trailer }\end{array}$} & B & 210 & 65 & 1.0 & 0.69 & 0.52 & 0.45 \\
\hline & B & 210 & 95 & 1.0 & 0.63 & 0.42 & 0.32 \\
\hline \multirow{2}{*}{$\begin{array}{c}\text { ASFT } \\
\text { vehicle }\end{array}$} & B & 700 & 65 & 1.0 & 0.70 & 0.50 & 0.40 \\
\hline & B & 700 & 95 & 1.0 & 0.60 & 0.40 & 0.32 \\
\hline \multirow{2}{*}{$\begin{array}{l}\text { ASFT } \\
\text { vehicle }\end{array}$} & B & 210 & 65 & 1.0 & 0.82 & 0.60 & 0.50 \\
\hline & $\mathrm{B}$ & 210 & 95 & 1.0 & 0.74 & 0.47 & 0.34 \\
\hline \multirow{2}{*}{$\begin{array}{c}\text { Runway } \\
\text { Friction } \\
\text { Tester } \\
\text { vehicle }\end{array}$} & B & 210 & 65 & 1.0 & 0.82 & 0.60 & 0.50 \\
\hline & B & 210 & 95 & 1.0 & 0.74 & 0.54 & 0.41 \\
\hline \multirow{2}{*}{$\begin{array}{c}\text { TATRA } \\
\text { Friction } \\
\text { Tester } \\
\text { vehicle }\end{array}$} & B & 210 & 65 & 1.0 & 0.76 & 0.57 & 0.48 \\
\hline & B & 210 & 95 & 1.0 & 0.67 & 0.52 & 0.42 \\
\hline
\end{tabular}

Besides, the aforementioned documents include a five-grade scale to assess snowy and iced pavements, which is done based on the efficiency of braking and measured friction coefficient (table 2). 
Table 2

The compilation of values of friction coefficients and assessment of the efficiency of braking on snowy and iced airfield pavements [5]

\begin{tabular}{|c|c|c|c||}
\hline $\begin{array}{c}\text { Friction coefficient } \\
\text { from measurements }\end{array}$ & $\begin{array}{c}\text { Efficiency assessment } \\
\text { of braking }\end{array}$ & Digit of the code \\
\hline 0.4 and more & Good & 5 \\
\hline $0.39-0.36$ & & Average to good & 4 \\
\hline $0.35-0.30$ & & Average & 3 \\
\hline $0.29-0.26$ & & Average to bad & 2 \\
\hline 0.25 and less & Bad & 1 \\
\hline
\end{tabular}

\subsection{Requirements regarding roughness of airfield pavements}

Requirements concerning texture depth, which have to be satisfied by airfield pavements, was determined in documents issued by world aviation institutions such as ICAO and FAA and the most important aviation European institution, which is EASA (European Aviation Safety Agency).

According to ICAO [13,3] and EASA [12], the mean texture depth should not be less than $1.0 \mathrm{~mm}$. According to FAA document [1], the required MTD value for new pavements is $1.14 \mathrm{~mm}$. In addition, pavements with texture depth (macro-texture) below $1 \mathrm{~mm}$ still may have good roughness properties but can require corrective actions aimed at improving its skid resistance properties, e.g. by grooving. The primary aim of the previously mentioned actions is the improvement of the system removing water from the pavement.

There is also a classification of runway (from A to E) based on the measured texture depth. It was developed by using measuring techniques of "sand and grease" and issued in 1971 by Engineering Sciences Data Unit (ESDU) [12,13].

Table 3

Classification of runway based on ESDU 71026 information regarding texture $[11,13]$

\begin{tabular}{|c|c|}
\hline Classification & Texture depth $[\mathbf{m m}]$ \\
\hline A & $0,10-0,14$ \\
\hline B & $0,15-0,24$ \\
\hline C & $0,25-0,50$ \\
\hline D & $0,51-1,00$ \\
\hline E & $1,01-2,54$ \\
\hline
\end{tabular}


Referring to this scale, it is assumed that texture in classification between B and $\mathrm{C}$ (MTD at the level of $0,25 \mathrm{~mm}$ ) ensures safe performance of air operations. Although the harmonised certification standards of some countries regard texture ensuring the properties of water removal and friction situated in the classification between $\mathrm{D}$ and $\mathrm{E}$ (MTD of $1,0 \mathrm{~mm})$.

\section{Ground investigations}

Ground investigations were conducted in two national airfields. The assessment evaluated the airfield pavements of runways (RW No.1 - pavement made from cement concrete and RW No.2 - pavement made from asphalt concrete) of the same age (approx. 2-year operation period).

\subsection{Scope of investigations}

The ground investigations included the measurements of friction coefficient and texture depth of airfield pavement. The assessment of roughness is conducted based on Airport Surface Friction Tester (ASFT) on T-10 trailer (RW No.1) and by using a manual, portable, airport surface friction measuring equipment T2Go (RW No.2) according to NO-17-A501:2015 Nawierzchnie lotniskowe. Badanie szorstkości [5] (Airfield pavements. Roughness testing). The measurement of texture depth of pavements was taken by using a volumetric method according to PN-EN 13036-1:2010 [6].

\subsection{Results of investigations}

Roughness tests were carried out for two parallel test routes for each of the assessed runways, taking into account that on RW No.2 the routes did not run on the whole length of RW. The routes run along the wheel tracks of the main landing gear of aircraft, i.e. approx. $4 \mathrm{~m}$ from the axis. Measurements of texture depth on RW No. 1 were conducted in three cross-sections and on RW No.2 in five cross-sections. For every cross-section, there were two test points located in the distance of approximately $4 \mathrm{~m}$ from an axis of the runway, one on the south of the runway (denoted as $\mathrm{S}$ ) and the other on the north (denoted as $\mathrm{N}$ ). The obtained results were summarised in the tabular (table 4) and graphical (fig. 5) form. 
Table 4

Results of ground investigations for pavement RW No.1

\begin{tabular}{|c|c|c|c|c|}
\hline $\begin{array}{l}\text { Airfield Functional } \\
\text { Elements }\end{array}$ & $\begin{array}{l}\text { Measuring } \\
\text { point }\end{array}$ & $\begin{array}{c}\text { Texture } \\
\text { Depth } \\
\text { [mm] }\end{array}$ & $\begin{array}{c}\text { Mean Texture } \\
\text { Depth } M T D \\
\text { [mm] }\end{array}$ & $\begin{array}{c}\text { Mean value of } \\
\text { friction } \\
\text { coefficient } \boldsymbol{\mu} \\
{[-]}\end{array}$ \\
\hline \multirow{6}{*}{$\begin{array}{c}\text { RW No. } 1 \\
\text { (cement concrete) }\end{array}$} & $0+500 / \mathrm{N}$ & 0.41 & \multirow{6}{*}{0.25} & \multirow{6}{*}{0.65} \\
\hline & $0+500 / \mathrm{S}$ & 0,21 & & \\
\hline & $1+600 / \mathrm{N}$ & 0.19 & & \\
\hline & $1+600 / \mathrm{S}$ & 0.22 & & \\
\hline & $2+700 / \mathrm{N}$ & 0.20 & & \\
\hline & $2+700 / \mathrm{S}$ & 0.28 & & \\
\hline \multirow{10}{*}{$\begin{array}{c}\text { RW No. } 2 \\
\text { (asphalt concrete) }\end{array}$} & $0+500 / \mathrm{N}$ & 0.37 & \multirow{10}{*}{0.47} & \multirow{10}{*}{0.60} \\
\hline & $0+500 / \mathrm{S}$ & 0.45 & & \\
\hline & $0+900 / \mathrm{N}$ & 0.46 & & \\
\hline & $0+900 / \mathrm{S}$ & 0.52 & & \\
\hline & $1+200 / \mathrm{N}$ & 0.43 & & \\
\hline & $1+200 / \mathrm{S}$ & 0.68 & & \\
\hline & $1+700 / \mathrm{N}$ & 0.36 & & \\
\hline & $1+700 / \mathrm{S}$ & 0.56 & & \\
\hline & $2+200 / \mathrm{N}$ & 0.46 & & \\
\hline & $2+200 / \mathrm{S}$ & 0.41 & & \\
\hline
\end{tabular}

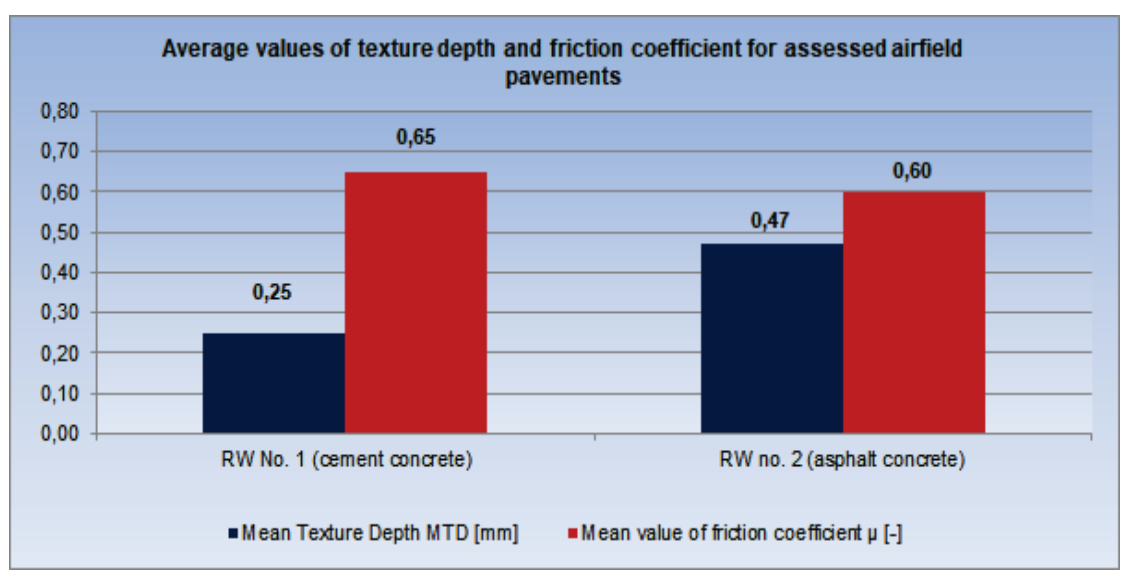

Fig. 5. Results of ground investigations as a part of the assessment of skid resistance properties of airfield pavements under test 
By analysing the results obtained during ground investigations it can be concluded that pavement made from asphalt concrete distinguishes itself with a very developed texture (value almost twice as large) than the one made from cement concrete, by the slight difference in the value of friction coefficient. Nevertheless, it should be stated that the obtained results confirm that pavements with texture depth below $1 \mathrm{~mm}$ still have good skid resistance properties and thus, can be safely operated by aircraft.

\section{Summary}

The applicable reference documents concerning the issue of the texture of airfield pavements raise many doubts. They do not necessarily relate to research methods, because they are somewhat understandable, but to the requirements and assessment criteria of the obtained results. They define the requirements almost solely for new airfield pavements. It also has to be underlined that they mainly relate to the runway surface. Besides, the aforementioned documents do not determine the minimum values as it is in the case of friction coefficient for individual age brackets of pavements, i.e.: 'values of new pavements', 'values for pavements in operation; after exceeding these values it is necessary to take corrective actions' and 'minimum threshold values', so there is no close link between criteria for parameter of texture depth and parameter of friction coefficient of airfield pavements.

Given the foregoing, the question arises what are the requirements of texture depth for pavement on other airfield functional elements (EFL). Due to lower speeds of aircraft moving on the airfield pavements, it may not be so crucial. However, the required minimum values of friction coefficient are not only limited to the runway but refer to the pavement of all EFL.

Therefore, the authors, in collaboration with a bigger research team, attempted to determine the impact of texture on the roughness of airfield pavement and rather a close dependence between these two properties.

As a part of this attempt, ground investigations have already been started with the use of friction tester of airfield pavements, which was adapted to the simultaneous, dynamic measurement of the texture of airfield pavements. The measurement is done with a laser profile scanner 2D/3D with high frequency.

Building upon the results accumulated during ground investigations, the authors want to define the influence of texture on the roughness of airfield pavements. Thus, it can provide the basis to develop acceptance criteria of 
texture's parameter for newly built and overhauled airfield pavements with reference to criteria relating to friction coefficient.

Currently, the authors continue their ground investigations aimed at enriching the existing results' base. The effects of the conducted works will be used in preparing subsequent reports concerning the texture of airfield pavements.

\section{References}

1. Advisory Circular no: 150/5320-12C, U.S. Department of Transportation, Federal Aviation Administration (FAA) 1997 z późn. zm.

2. Contractor's Final Report for NCHRP Project 01-43, Guide for Pavement Friction, National Cooperative Highway Research Program, USA, February 2009.

3. Doc. 9157 ICAO AN/901 Aerodrome Design Manual Part 1 - Runways, ICAO, edycja trzecia, 2006.

4. Doc. 9137 ICAO AN/898 Airport Service Manual Part 2 - Pavement Surface Conditions, ICAO, edycja czwarta, 2002.

5. NO-17-A501:2015 Nawierzchnie lotniskowe. Badanie szorstkości.

6. PN-EN 13036-1:2010 Cechy powierzchniowe nawierzchni drogowych i lotniskowych. Metody badań. Część 1: Pomiar głębokości makrotekstury metodą objętościową.

7. PN-EN ISO 13473-1:2005 Charakterystyka struktury nawierzchni przy użyciu profili powierzchniowych. Część 1: Określenie średniego profilu głębokości.

8. Ueckermann A., Wang D., Oeser M., Steinauer B.: Calculation of skid resistance from texture, Journal of Traffic and Transportation Engineering, 2/2015.

9. Wasilewska M., Gardziejczyk W., Gierasimiuk P.: Ocena właściwości przeciwpoślizgowych nawierzchni betonowych z odkrytym kruszywem w początkowym okresie ich użytkowania, Roads and Bridges - Drogi i Mosty, nr 16, 2017.

10. Wesołowski M., Iwanowski P.: Interpretacja właściwości przeciwpoślizgowych nawierzchni drogowych i lotniskowych na podstawie pomiaru współczynnika tarcia, Autobusy: technika, eksploatacja, systemy transportowe, 12/2017.

11. Wytyczne nr 2 Prezesa Urzędu Lotnictwa Cywilnego z dnia 25 stycznia 2016 r. w sprawie metod oceny, pomiaru oraz raportowania stanu nawierzchni drogi startowej, 2016.

12. Załącznik do Decyzji Dyrektora Wykonawczego EASA nr 2017/021/R z dnia 08 grudnia 2017 r. wdrażającej wydanie czwarte Specyfikacji Certyfikacyjnych (CS) oraz Materiałów Zawierających Wytyczne (GM) do Projektowania Lotnisk CSADR-DSN, 2017.

13. Załącznik 14 ICAO do Konwencji o Międzynarodowym Lotnictwie Cywilnym, Lotniska Tom I - Projektowanie i eksploatacja lotnisk, wydanie 6, 2013. 


\section{WLAŚCIWOŚCI PRZECIWPOŚLIZGOWE NAWIERZCHNI LOTNISKOWYCH W ASPEKCIE OBOWIĄZUJĄCYCH PRZEPISÓW NORMATYWNYCH}

\section{Wstęp}

Stan techniczny nawierzchni lotniskowej charakteryzuje ją w aspekcie bezpieczeństwa wykonywania operacji lotniczych. Właściwości przeciwpoślizgowe są jednym z elementów procesu oceny stanu technicznego nawierzchni. Określaja przyczepność opony statku powietrznego do nawierzchni, czyli zdolność do wytwarzania siły tarcia pomiędzy nawierzchnią elementu funkcjonalnego lotniska (EFL) a kołami statku powietrznego w warunkach wzajemnego poślizgu.

Podstawowym parametrem mającym decydujące znaczenie przy określaniu stanu nawierzchni lotniskowej w zakresie właściwości przeciwpoślizgowych jest współczynnik tarcia, definiowany jako bezwymiarowy stosunek siły tarcia pomiędzy dwoma ciałami do normalnej siły nacisku tych dwóch ciał [11].

$$
\mu=\frac{T}{N}
$$

gdzie:

$\mu$ - współczynnik tarcia,

$T$ - pozioma siła tarcia przy hamowaniu koła [N],

$N$ - pionowa reakcja podłoża od obciążenia koła [N].

Jest to parametr determinujący prawidłową trajektorię poruszającego się statku powietrznego na polu wzlotów lotniska. Stosowane systemy hamulcowe nie zadziałają, jeśli koło samolotu nie będzie miało odpowiedniej przyczepności do nawierzchni. W dalszym ciągu odnotowywane są zdarzenia lotnicze związane z wypadnięciem samolotu poza drogę startową, spowodowane właśnie utratą przyczepności. Sytuacje te wymuszaja, aby już na etapie projektowania nawierzchni lotniskowych projektanci uwzględniali uzyskiwane w przyszłości parametry przeciwpoślizgowe nawierzchni. 
W praktyce dąży się do tego, aby po przyziemieniu samolot poruszał się ruchem opóźnionym, to znaczy żeby siły hamowania zostały zrównoważone przez siłę tarcia. W sytuacji gdy siły hamowania przewyższają siły tarcia, koło zaczyna się ślizgać po nawierzchni, czego efektem jest częściowa lub całkowita utrata przez pilota kontroli nad maszyną. W czasie hamowania statku powietrznego, przez hamulce generowany jest moment hamowania $\left(M_{\mathrm{H}}\right)$, który przenoszony jest na obwód koła, a to z kolei powoduje powstanie między oponą a nawierzchnią siły hamowania (rys. 1).

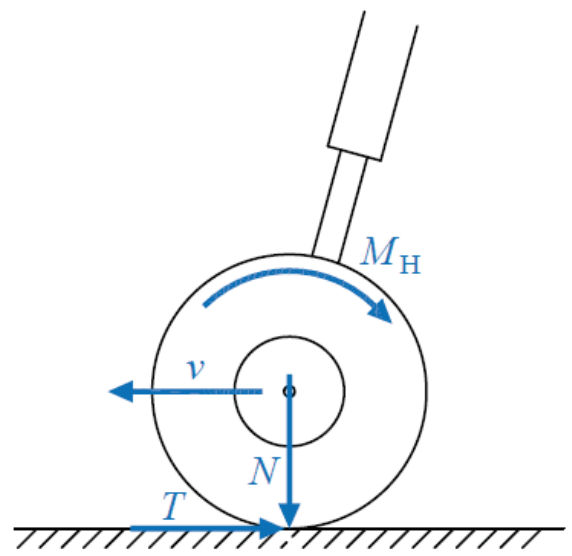

Rys. 1. Schemat sił działających na hamujące koło: $\mathrm{MH}$ - moment hamujący generowany przez hamulce, $\mathrm{T}$ - siła tarcia równoważąca moment hamujący, $\mathrm{N}$ - siła nacisku koła, $\mathrm{v}$ - prędkość środka koła w kierunku wzdłużnym

Drugim elementem składowym charakterystyki tarcia powierzchni styku opona/nawierzchnia jest tekstura nawierzchni (mikrotekstura i makrotekstura). Mówiąc o mikroteksturze nawierzchni, mamy na myśli nierówności w zakresie fal o długości mniejszej niż $0,5 \mathrm{~mm}$ (tekstura o głębokości do $0,5 \mathrm{~mm}$ ). Natomiast makrotekstura odnosi się do nierówności nawierzchni w zakresie fal o długości 0,5-50 mm (tekstura o głębokości powyżej $0,5 \mathrm{~mm}$ ) [2,7,10].

Mikrotekstura związana jest $\mathrm{z}$ teksturą pojedynczych kamieni (ziaren kruszywa) i jest trudna do wychwycenia gołym okiem. Może ulegać zmianie w krótkim czasie bez łatwego wykrycia. Ocena mikrotekstury przeprowadzana jest w sposób pośredni na podstawie wskaźnika polerowalności kruszyw PSV [9], który stanowi wartość uzyskaną $\mathrm{w}$ wyniku pomiaru tarcia zgodnie $\mathrm{z}$ międzynarodowymi standardami. Standardy te definiują minima PSV, umożliwiające wybór materiału z dobrą mikroteksturą [12]. 
Makrotekstura natomiast związana jest $\mathrm{z}$ teksturą pomiędzy pojedynczymi kamieniami (ziarnami kruszywa) i umożliwia przede wszystkim odprowadzanie wody z płaszczyzny kontaktu opona/nawierzchnia, szczególnie przy dużych prędkościach. Tworzona jest głównie przez rozmiar używanego kruszywa lub przez obróbkę nawierzchni. Jeżeli nawierzchnia charakteryzuje się dobrą makrotekstura, pozwalającą na odprowadzenie wody spod opony, wówczas tarcie w mniejszym stopniu będzie zależeć od prędkości. Natomiast przy złej makroteksturze zaobserwujemy zwiększony spadek wartości tarcia $\mathrm{w}$ miarę wzrostu prędkości.

\section{Metody oceny właściwości przeciwpoślizgowych}

Zarówno szorstkość, jak i tekstura nawierzchni lotniskowych są cechami określającymi jej właściwości przeciwpoślizgowe, czyli sprawdzane są w tym samym celu. Jednak metody pomiarowe stosowane in situ do określania tych parametrów, tzn. współczynnika tarcia i głębokości tekstury różnią się od siebie. Obecnie do oceny szorstkości nawierzchni lotniskowych korzystamy z metody opartej na pomiarze ciągłym, natomiast do oceny głębokości tekstury stosowane są metody opierające się na pomiarach punktowych.

\subsection{Szorstkość nawierzchni lotniskowych}

Pomiary współczynnika tarcia nawierzchni lotniskowych realizowane są zgodnie z Normą Obronną NO-17-A501:2015 Nawierzchnie lotniskowe. Badanie szorstkości [5], która została opracowana w oparciu o dokumenty zagraniczne $[13,1,4]$.

Norma zawiera wykaz urządzeń dopuszczonych do oceny szorstkości nawierzchni lotniskowych, które umożliwiają pomiar ciagły współczynnika tarcia, odzwierciedlając zjawisko zachodzące między kołem poruszającego się statku powietrznego a nawierzchnią lotniskową (tab. 1). Ponadto, urządzenie takie powinno spełniać wymogi dotyczace opony pomiarowej oraz układu zraszającego nawierzchnię. Szczegółowe parametry opony pomiarowej, uwzględniające typ opony i odpowiadające im wartości ciśnienia, zawiera dokument [4]. Dopuszcza się również stosowanie innych urządzeń pomiarowych niż wymienione $\mathrm{w}$ normie, które muszą być jednocześnie poddane procedurze testowej [4]. 


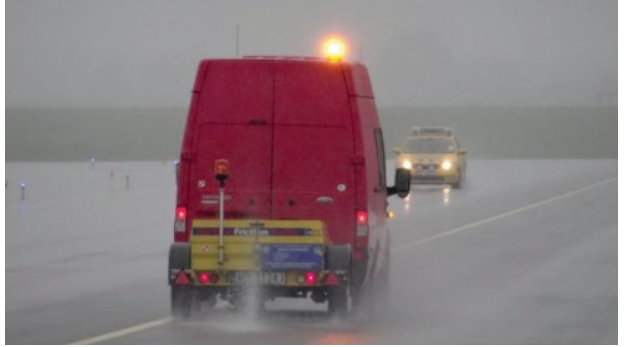

(a)

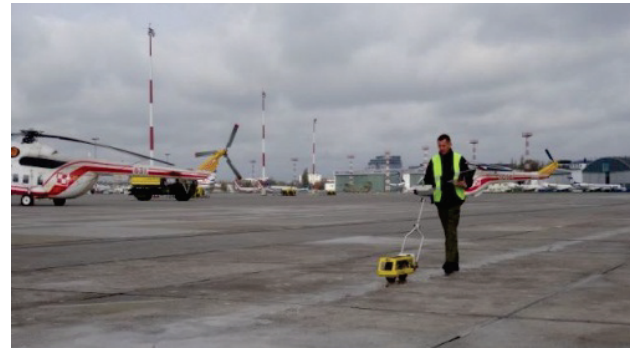

(b)

Rys. 2. Tester tarcia ASFT na przyczepie T-10 (a); ręczny, przenośny tester tarcia ASFT typu T2Go (b) [źródło: archiwum ITWL]

$\mathrm{Na}$ polskich obiektach lotniskowych obecnie najpopularniejszymi urządzeniami do pomiaru współczynnika tarcia są urządzenia firmy ASFT, zamontowane na przyczepie (rys. 2a) lub na autonomicznym pojeździe. Urządzenia te umożliwiają ciagły, liniowy pomiar współczynnika tarcia pomiędzy nawierzchnią lotniskową a wzorcowym kołem samolotu, z prędkością pomiarową $65 \mathrm{lub} 95 \mathrm{~km} / \mathrm{h}$. Wyposażone są w zbiornik na wodę oraz mechanizm podający wodę pod koło pomiarowe w celu osiagnięcia wymaganego w normach filmu wodnego o grubości nie mniejszej niż $1 \mathrm{~mm}$.

Mniejsze EFL, których wymiary geometryczne uniemożliwiają pomiar przy prędkości 65 lub $95 \mathrm{~km} / \mathrm{h}$ można badać, używając ręcznego testera szorstkości T2Go (rys. 2b) lub - coraz rzadziej - urządzenia BVS-1. Tester T2Go umożliwia ciagły pomiar współczynnika tarcia przy niskich prędkościach, a przeprowadzona korelacja między nim i przyczepowym testerem T-10 pozwala na odniesienie się do wymagań zawartych w podanych wcześniej dokumentach.

\subsection{Tekstura nawierzchni lotniskowych}

Ocena tekstury nawierzchni lotniskowych aktualnie wykonywana jest metodą wolumometryczną (pomiar średniej głębokości tekstury - MTD) wg PN-EN 13036-1:2010 Cechy powierzchniowe nawierzchni drogowych i lotniskowych. Metody badań. Czesść 1: Pomiar głębokości makrotekstury metoda objętościowa [6] lub profilometryczną (pomiar średniej głębokości profilu MPD) wg PN-EN ISO 13473-1:2005 Charakterystyka struktury nawierzchni przy użyciu profili powierzchniowych. Część 1: Określenie średniego profilu głębokości [7].

Metoda objętościowa, inaczej zwana metodą piasku kalibrowanego (lub metodą łaty piaskowej), jest od wielu już lat powszechnie stosowana na całym świecie do pomiaru tekstury nawierzchni i szczegółowo została opisana 
w dokumentach ICAO (International Civil Aviation Organization) [4] oraz FAA (Federal Aviation Administration) [1].

Zakres stosowania metody to od $0,25 \mathrm{~mm}$ do $5 \mathrm{~mm} \mathrm{MTD}$. Polega ona na rozprowadzeniu $\mathrm{w}$ sposób kolisty określonej objętości materiału ziarnistego (zwykle piasku lub szklanych kulek) na badanej nawierzchni. Do pomiaru obecnie używa się pełnych kulek szklanych, z których co najmniej 90\% przechodziło przez sito o oczkach $0,25 \mathrm{~mm}$ i pozostawało na sicie $0,18 \mathrm{~mm}$. Materiał rozprowadzany jest na nawierzchni za pomocą płaskiego, twardego krążka o średnicy $65 \mathrm{~mm}$ i grubości około $25 \mathrm{~mm}$, pokrytego na spodniej powierzchni warstwą twardej gumy. Wartością mierzoną jest uśredniona średnica utworzonej laty (rys. 3).

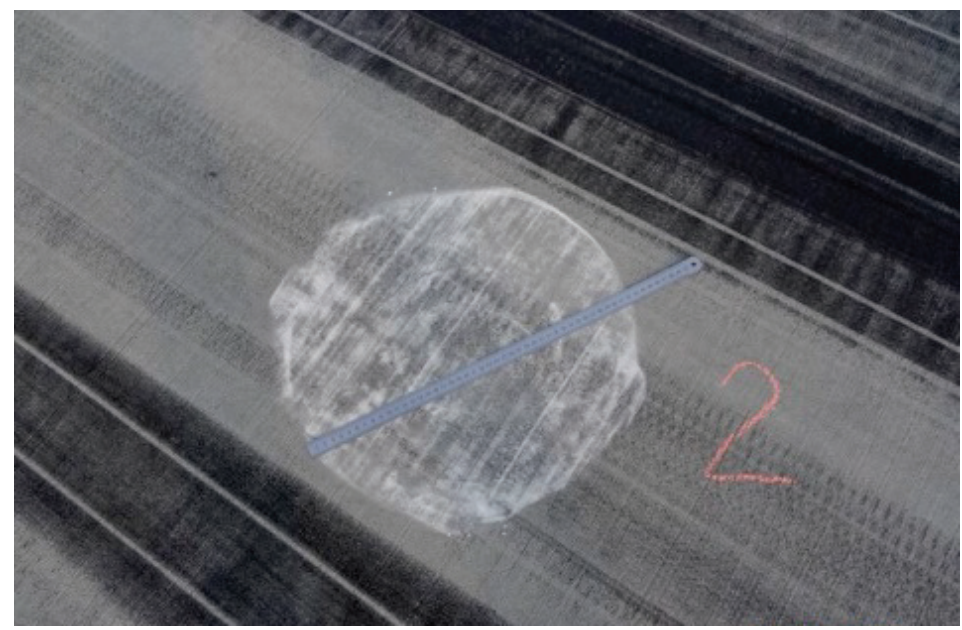

Rys. 3. Widok utworzonej łaty [źródło: archiwum ITWL]

Wynik badania stanowi średnia głębokość tekstury otrzymana ze wzoru:

$$
M T D=\frac{4 V}{\pi D^{2}}
$$

gdzie:

$M T D$ - średnia głębokość tekstury [mm],

$V$ - objętość próbki materiału ziarnistego $\left[\mathrm{mm}^{3}\right]$,

$D$-średnia średnica koła pokrytego materiałem ziarnistym [mm].

Objętość próbki materiału ziarnistego obliczana jest według wzoru: 


$$
V=\frac{\pi d^{2} h}{4}
$$

gdzie:

$d$ - wewnętrzna średnica pojemnika wypełnionego materiałem ziarnistym [mm], $h$ - wysokość pojemnika wypełnionego materiałem ziarnistym [mm].

Metoda profilometryczna wykorzystuje pomiar profilu powierzchni nawierzchni przez czujnik laserowy o dużej częstotliwości próbkowania (urządzenia pomiarowe nazywane są profilografami lub profilometrami). Podczas pomiaru tą metodą otrzymujemy profil nawierzchni, który poddawany jest dalszej analizie, i wyznacza się tzw. średnią głębokość profilu - MPD. Profil przedstawia nawierzchnię w dwóch wymiarach i opisany jest przez dwie współrzędne: odległość (wzdłuż powierzchni nawierzchni) i amplitudę (prostopadła do powierzchni nawierzchni). ma Zakres zastosowania metody profilometrycznej wynosi od $0 \mathrm{~mm}$ do $5 \mathrm{~mm} M P D$, a wartość progowa pomiędzy mikrotekstura a makroteksturą $0,5 \mathrm{~mm}$.

Wartość $M P D$ może być przekształcona w szacowaną głębokość tekstury $E T D$. Do tego należy zastosować równanie transformacji:

$$
E T D=0,2+0,8 M P D
$$

Uzyskana w ten sposób wartość ETD powinna być jak najbardziej zbliżona do wartości MTD.

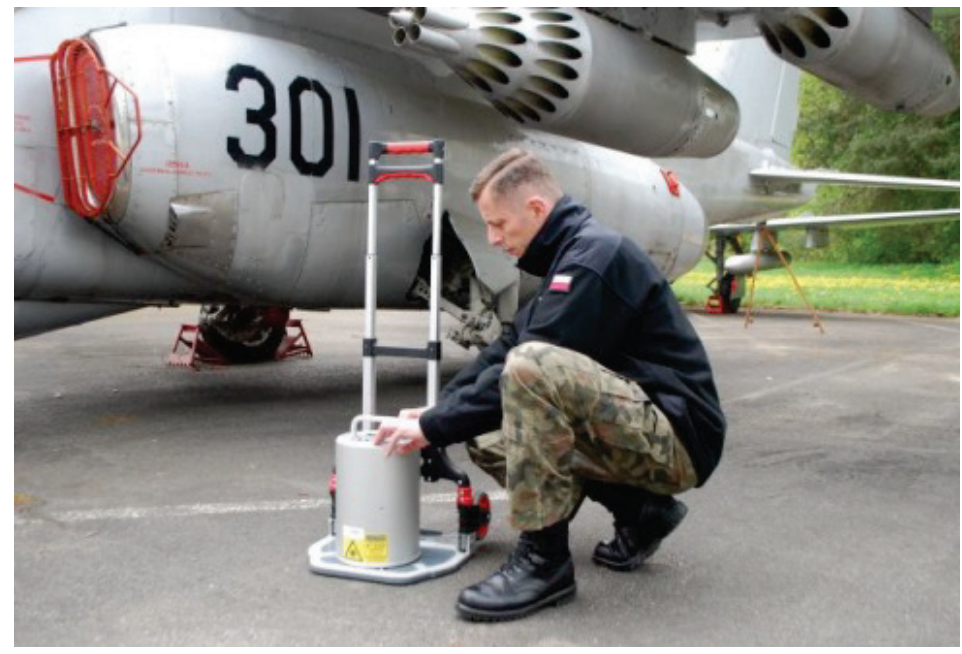

Rys. 4. Urządzenie ELATextur do pomiaru makrotekstury [źródło: archiwum ITWL] 


\section{Wymagania w zakresie właściwości przeciwpoślizgowych}

Zarówno szorstkość jak i tekstura nawierzchni lotniskowych są cechami sprawdzanymi w tym samym celu, może się wydawać, że wymagania $\mathrm{w}$ tym zakresie będą ze sobą powiązane. W rzeczywistości jednak wygląda to trochę inaczej.

\subsection{Wymagania w zakresie szorstkości nawierzchni lotniskowych}

Wymagania w zakresie wartości współczynnika tarcia dla nawierzchni lotniskowych przedstawione są w wielu dokumentach międzynarodowych [13, 1,4] oraz polskiej normie obronnej [5]. Dokumenty te podają wartości współczynnika tarcia, jakie powinny być uzyskiwane na nawierzchniach EFL, aby możliwe było prowadzenie na nich operacji lotniczych przy zachowaniu bezpieczeństwa i niezawodności statków powietrznych (tab. 1).

Tabela 1

Wymagania wg NO-17-A501:2015 Nawierzchnie lotniskowe - Badanie szorstkości [5]

\begin{tabular}{|c|c|c|c|c|c|c|c|}
\hline \multirow[b]{2}{*}{$\begin{array}{l}\text { Urządzenie } \\
\text { pomiarowe }\end{array}$} & \multicolumn{2}{|c|}{$\begin{array}{c}\text { Opona } \\
\text { testowa }\end{array}$} & \multirow[b]{2}{*}{$\begin{array}{c}\text { Prędkość } \\
\text { pomiar. } \\
{[\mathrm{km} / \mathrm{h}]}\end{array}$} & \multirow[b]{2}{*}{$\begin{array}{c}\text { Grubość } \\
\text { filmu } \\
\text { wodnego } \\
\text { [mm] }\end{array}$} & \multicolumn{3}{|c|}{ Współczynnik tarcia } \\
\hline & ह & 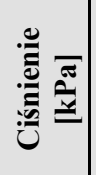 & & & $\begin{array}{c}\text { Wartości } \\
\text { projektowe } \\
\text { dla nowych } \\
\text { nawierzchni }\end{array}$ & $\begin{array}{l}\text { Wartości do } \\
\text { planowania } \\
\text { dzialań } \\
\text { naprawczych }\end{array}$ & $\begin{array}{l}\text { Wartości } \\
\text { minimalne } \\
\text { (graniczne) }\end{array}$ \\
\hline \multirow{2}{*}{$\begin{array}{l}\text { Przyczepa } \\
\text { Surface } \\
\text { Friction Tester } \\
\text { (ASFT) }\end{array}$} & $\mathrm{B}$ & 700 & 65 & 1,0 & 0,70 & 0,50 & 0,40 \\
\hline & B & 700 & 95 & 1,0 & 0,60 & 0,40 & 0,32 \\
\hline \multirow{2}{*}{$\begin{array}{l}\text { Przyczepa } \\
\text { Mu-meter }\end{array}$} & A & 70 & 65 & 1,0 & 0,72 & 0,52 & 0,42 \\
\hline & A & 70 & 95 & 1,0 & 0,66 & 0,38 & 0,26 \\
\hline \multirow{2}{*}{$\begin{array}{l}\text { Przyczepa } \\
\text { Skiddometer }\end{array}$} & B & 210 & 65 & 1,0 & 0,82 & 0,60 & 0,50 \\
\hline & B & 210 & 95 & 1,0 & 0,74 & 0,47 & 0,34 \\
\hline \multirow{2}{*}{$\begin{array}{l}\text { Przyczepa } \\
\text { RUNAR }\end{array}$} & B & 210 & 65 & 1,0 & 0,69 & 0,52 & 0,45 \\
\hline & $\mathrm{B}$ & 210 & 95 & 1,0 & 0,63 & 0,42 & 0,32 \\
\hline
\end{tabular}


Właściwości przeciwpoślizgowe nawierzchni lotniskowych w aspekcie obowiąujących przepisów...

\begin{tabular}{|c|c|c|c|c|c|c|c|}
\hline \multirow[b]{2}{*}{$\begin{array}{l}\text { Urządzenie } \\
\text { pomiarowe }\end{array}$} & \multicolumn{2}{|c|}{$\begin{array}{l}\text { Opona } \\
\text { testowa }\end{array}$} & \multirow[b]{2}{*}{$\begin{array}{c}\text { Prędkość } \\
\text { pomiar. } \\
{[\mathbf{k m} / \mathbf{h}]}\end{array}$} & \multirow[b]{2}{*}{$\begin{array}{c}\text { Grubość } \\
\text { filmu } \\
\text { wodnego } \\
\text { [mm] }\end{array}$} & \multicolumn{3}{|c|}{ Współczynnik tarcia } \\
\hline & ह & 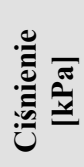 & & & $\begin{array}{c}\text { Wartości } \\
\text { projektowe } \\
\text { dla nowych } \\
\text { nawierzchni }\end{array}$ & $\begin{array}{l}\text { Wartości do } \\
\text { planowania } \\
\text { działań } \\
\text { naprawczych }\end{array}$ & $\begin{array}{c}\text { Wartości } \\
\text { minimalne } \\
\text { (graniczne) }\end{array}$ \\
\hline \multirow{2}{*}{$\begin{array}{l}\text { Pojazd Airport } \\
\text { Surface } \\
\text { Friction Tester } \\
\text { (ASFT) }\end{array}$} & $\mathrm{B}$ & 700 & 65 & 1,0 & 0,70 & 0,50 & 0,40 \\
\hline & B & 700 & 95 & 1,0 & 0,60 & 0,40 & 0,32 \\
\hline \multirow{2}{*}{$\begin{array}{l}\text { Pojazd Surface } \\
\text { Friction Tester }\end{array}$} & $\mathrm{B}$ & 210 & 65 & 1,0 & 0,82 & 0,60 & 0,50 \\
\hline & $\mathrm{B}$ & 210 & 95 & 1,0 & 0,74 & 0,47 & 0,34 \\
\hline \multirow{2}{*}{$\begin{array}{l}\text { Pojazd } \\
\text { Runway } \\
\text { Friction Tester }\end{array}$} & B & 210 & 65 & 1,0 & 0,82 & 0,60 & 0,50 \\
\hline & $\mathrm{B}$ & 210 & 95 & 1,0 & 0,74 & 0,54 & 0,41 \\
\hline \multirow{2}{*}{$\begin{array}{l}\text { Pojazd } \\
\text { TATRA } \\
\text { Friction Tester }\end{array}$} & $\mathrm{B}$ & 210 & 65 & 1,0 & 0,76 & 0,57 & 0,48 \\
\hline & B & 210 & 95 & 1,0 & 0,67 & 0,52 & 0,42 \\
\hline
\end{tabular}

Ponadto, wymienione dokumenty zawierają pięciostopniową skalę do oceny nawierzchni zaśnieżonych i pokrytych lodem, która dokonywana jest na podstawie skuteczności hamowania i zmierzonego współczynnika tarcia (tab. 2).

Tabela 2

Zestawienie wartości współczynników tarcia i oceny skuteczności hamowania dla zaśnieżonych i pokrytych lodem nawierzchni lotniskowych [5]

\begin{tabular}{|c|c|c|}
\hline $\begin{array}{c}\text { Współczynnik tarcia } \\
\text { z pomiarów }\end{array}$ & $\begin{array}{c}\text { Ocena skuteczności } \\
\text { hamowania }\end{array}$ & $\begin{array}{c}\text { Cyfra } \\
\text { kodu }\end{array}$ \\
\hline 0,40 i więcej & Dobra & 5 \\
\hline $0,39-0,36$ & średnia do dobrej & 4 \\
\hline $0,35-0,30$ & Średnia & 3 \\
\hline $0,29-0,26$ & średnia do złej & 2 \\
\hline 0,25 i mniej & Zła & 1 \\
\hline
\end{tabular}




\subsection{Wymagania w zakresie tekstury nawierzchni lotniskowych}

Wymagania dotyczące głębokości tekstury, jakie muszą spełniać nawierzchnie lotniskowe, zostały określone $\mathrm{w}$ dokumentach wydanych przez światowe instytucje lotnicze, takie jak ICAO i FAA, oraz najważniejszą lotniczą instytucję europejska, czyli EASA (European Aviation Safety Agency).

Według ICAO [13,3] i EASA [12] średnia głębokość tekstury nie powinna być mniejsza niż 1,0 mm. Zgodnie z dokumentem FAA [1] wymagana wartość MTD dla nowych nawierzchni to $1,14 \mathrm{~mm}$, co więcej nawierzchnie charakteryzujące się głębokością tekstury (makrotekstury) poniżej $1 \mathrm{~mm}$ wciąż mogą wykazywać dobre właściwości pod względem szorstkości, ale w niedługim czasie mogą wymagać podjęcia działań polepszających ich właściwości przeciwpoślizgowe, np. poprzez rowkowanie. Podstawowym celem tego zabiegu jest poprawa systemu odprowadzania wody z nawierzchni.

Istnieje również klasyfikacja drogi startowej (od A do E) w oparciu o zmierzoną głębokość tekstury. Opracowana została przy użyciu technik pomiaru „piaskiem i smarem” i wydana w 1971 r. przez Engineering Sciences Data Unit (ESDU) [12,13].

Tabela 3

Klasyfikacja drogi startowej w oparciu o informacje ESDU 71026 dotyczące tekstury $[11,13]$

\begin{tabular}{|c|c|}
\hline Klasyfikacja & $\begin{array}{c}\text { Glębokość tekstury } \\
{[\mathbf{m m}]}\end{array}$ \\
\hline A & $0,10-0,14$ \\
\hline B & $0,15-0,24$ \\
\hline C & $0,25-0,50$ \\
\hline D & $0,51-1,00$ \\
\hline E & $1,01-2,54$ \\
\hline
\end{tabular}

Odnosząc się do tej skali, przyjmuje się, że tekstura w klasyfikacji pomiędzy B i C (MTD na poziomie $0,25 \mathrm{~mm}$ ) zapewnia bezpieczne wykonywanie operacji lotniczych. Aczkolwiek ujednolicone standardy certyfikacyjne niektórych państw, dotyczą tekstury zapewniającej właściwości odprowadzania wody oraz tarcia znajdującej się w klasyfikacji pomiędzy D i E (MTD na poziomie 1,0 mm). 


\section{Badania terenowe}

Badania terenowe przeprowadzono w dwóch krajowych portach lotniczych. Ocenie poddano nawierzchnie lotniskowe dróg startowych (DS nr 1 - nawierzchnia wykonana w technologii betonu cementowego i DS nr 2 - nawierzchnia wykonana $\mathrm{w}$ technologii betonu asfaltowego), będące $\mathrm{w}$ podobnym wieku (ok. 2-letni okres eksploatacji).

\subsection{Zakres badań}

Zakres badań terenowych obejmował pomiary współczynnika tarcia oraz głębokości tekstury nawierzchni lotniskowej. Ocena stanu szorstkości przeprowadzona została za pomocą testera szorstkości nawierzchni lotniskowych ASFT (Airport Surface Friction Tester) na przyczepie T-10 (DS nr 1) oraz przy użyciu ręcznego, przenośnego testera tarcia T2Go (DS nr 2), zgodnie z NO-17A501:2015 Nawierzchnie lotniskowe. Badanie szorstkości [5]. Pomiarów głębokości tekstury nawierzchni dokonano metodą objętościową, zgodnie z PNEN 13036-1:2010 [6].

\subsection{Wyniki badań}

Badania szorstkości przeprowadzono na dwóch równoległych trasach pomiarowych dla każdej z ocenianych dróg startowych, przy czym na DS nr 2 trasy nie przebiegały na całej długości DS. Trasy przebiegały w śladzie kół podwozia głównego statków powietrznych, tj. ok. $4 \mathrm{~m}$ od osi. Pomiary głębokości tekstury na DS nr 1 wykonano w trzech przekrojach poprzecznych, a na DS nr 2 w pięciu przekrojach poprzecznych. Na każdy przekrój przypadały dwa punkty badawcze usytuowane $\mathrm{w}$ odległości około $4 \mathrm{~m}$ od osi drogi startowej, jeden po stronie południowej drogi startowej (oznaczony jako S), drugi po stronie północnej (oznaczony jako $\mathrm{N}$ ). Uzyskane wyniki przedstawiono $\mathrm{w}$ formie tabelarycznej (tab. 4) oraz graficznej (rys. 5). 
Tabela 4

Wyniki badań terenowych dla nawierzchni DS nr 1

\begin{tabular}{|c|c|c|c|c|}
\hline $\begin{array}{c}\text { Element } \\
\text { Funkcjonalny } \\
\text { Lotniska }\end{array}$ & $\begin{array}{c}\text { Punkt } \\
\text { pomiarowy }\end{array}$ & $\begin{array}{c}\text { Glębokość } \\
\text { tekstury } \\
M T D \\
{[\mathrm{~mm}]} \\
\end{array}$ & $\begin{array}{c}\text { Średnia głębokość } \\
\text { tekstury } M T D \\
\text { [mm] }\end{array}$ & $\begin{array}{c}\text { Średnia wartośćc } \\
\text { współczynnika } \\
\text { tarcia } \mu \\
{[-]} \\
\end{array}$ \\
\hline \multirow{6}{*}{$\begin{array}{c}\text { DS nr } 1 \\
\text { (beton cementowy) }\end{array}$} & $0+500 / \mathrm{N}$ & 0,41 & \multirow{6}{*}{0,25} & \multirow{6}{*}{0,65} \\
\hline & $0+500 / \mathrm{S}$ & 0,21 & & \\
\hline & $1+600 / \mathrm{N}$ & 0,19 & & \\
\hline & $1+600 / \mathrm{S}$ & 0,22 & & \\
\hline & $2+700 / \mathrm{N}$ & 0,20 & & \\
\hline & $2+700 / \mathrm{S}$ & 0,28 & & \\
\hline \multirow{10}{*}{$\begin{array}{c}\text { DS nr } 2 \\
\text { (beton asfaltowy) }\end{array}$} & $0+500 / \mathrm{N}$ & 0,37 & \multirow{10}{*}{0,47} & \multirow{10}{*}{0,60} \\
\hline & $0+500 / \mathrm{S}$ & 0,45 & & \\
\hline & $0+900 / \mathrm{N}$ & 0,46 & & \\
\hline & $0+900 / \mathrm{S}$ & 0,52 & & \\
\hline & $1+200 / \mathrm{N}$ & 0,43 & & \\
\hline & $1+200 / \mathrm{S}$ & 0,68 & & \\
\hline & $1+700 / \mathrm{N}$ & 0,36 & & \\
\hline & $1+700 / \mathrm{S}$ & 0,56 & & \\
\hline & $2+200 / \mathrm{N}$ & 0,46 & & \\
\hline & $2+200 / \mathrm{S}$ & 0,41 & & \\
\hline
\end{tabular}

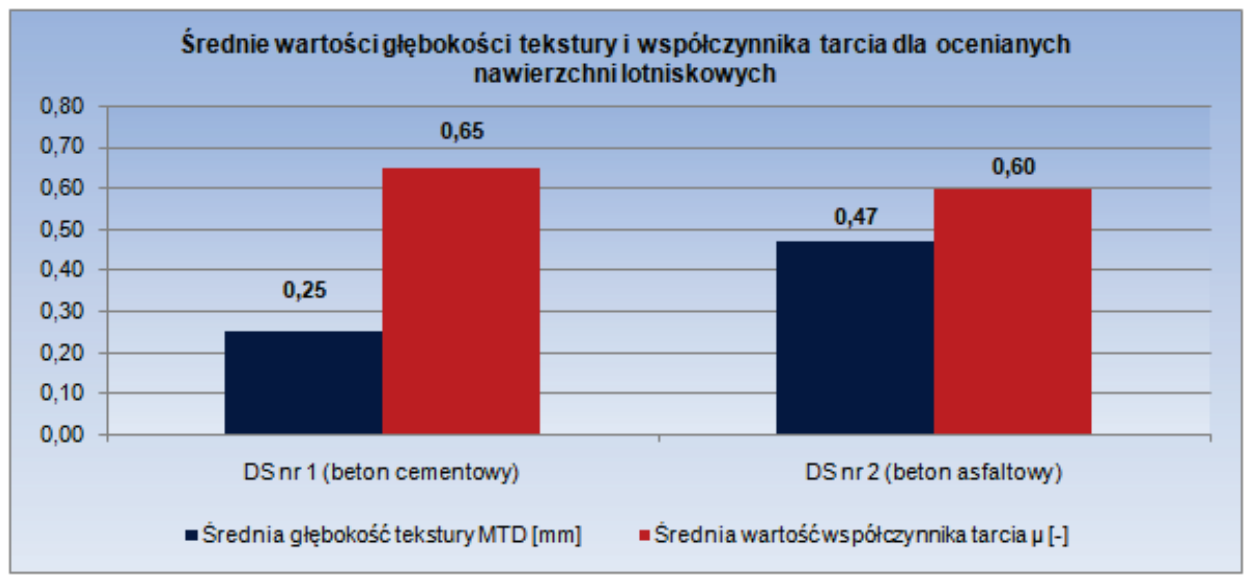

Rys. 5. Wyniki badań terenowych $\mathrm{w}$ ramach oceny właściwości przeciwpoślizgowych badanych nawierzchni lotniskowych 
Analizując uzyskane podczas badań terenowych wyniki, można stwierdzić, że nawierzchnia wykonana $\mathrm{w}$ technologii betonu asfaltowego wykazuje bardziej rozbudowaną teksturę (wartość większa prawie dwukrotnie) niż ta wykonana z betonu cementowego, przy niewielkiej różnicy wartości współczynnika tarcia. Niemniej jednak, uzyskane wyniki potwierdzają że nawierzchnie o głębokości tekstury poniżej $1 \mathrm{~mm}$ wciąż mogą wykazywać dobre właściwości przeciwpoślizgowe, a co za tym idzie mogą być bezpiecznie eksploatowane przez statki powietrzne.

\section{Podsumowanie}

Obowiązujące dokumenty odniesienia dotyczące tematyki tekstury nawierzchni lotniskowych w praktyce budzą wiele wątpliwości. Może nie do samych metod badawczych, ponieważ są one raczej zrozumiałe, ale w zakresie wymagań oraz kryteriów oceny uzyskanych wyników. Definiują wymagania praktycznie tylko dla nowych nawierzchni lotniskowych. Należy również zwrócić uwagę, że dotyczą one przede wszystkim nawierzchni drogi startowej. Ponadto, dokumenty te nie określają minimalnych wartości, tak jak jest to $\mathrm{w}$ przypadku współczynnika tarcia dla poszczególnych przedziałów wiekowych nawierzchni, tj.: „wartości dla nowych nawierzchni”, „wartości dla nawierzchni będących w eksploatacji, po przekroczeniu których należy podjąć działania naprawcze” oraz „minimalnych wartości granicznych", czyli nie ma ścisłego powiązania kryteriów dla parametru głębokości tekstury i parametru współczynnika tarcia nawierzchni lotniskowych.

Biorąc pod uwagę powyższe, nasuwa się pytanie - jakie są wymagania w zakresie głębokości tekstury dla nawierzchni na pozostałych EFL? Może ze względu na mniejsze prędkości, z jakimi poruszają się po nich statki powietrzne, nie jest to aż tak istotne. Jednak wymagane minimalne wartości współczynnika tarcia nie ograniczają się wyłącznie do drogi startowej, ale dotyczą nawierzchni wszystkich EFL.

Wobec tego autorzy wspólnie z szerszym zespołem badawczym podjęli próbę mającą na celu określenie wpływu tekstury na szorstkość nawierzchni lotniskowych, a raczej ścisłej zależności pomiędzy tymi dwiema właściwościami.

$\mathrm{W}$ ramach podjętej próby rozpoczęto już badania terenowe testerem tarcia nawierzchni lotniskowych, który został przystosowany do równoczesnego, dynamicznego pomiaru tekstury nawierzchni lotniskowych. Pomiar odbywa się za pomocą laserowego skanera profilu 2D/3D o wysokiej częstotliwości.

Na podstawie wyników zgromadzonych podczas badań terenowych, autorzy chcą określić wpływ tekstury na szorstkość nawierzchni lotniskowych. Co z kolei ma stanowić podstawę do opracowania kryteriów odbiorczych parametru tekstury 
dla nowo budowanych i remontowanych nawierzchni lotniskowych w odniesieniu do kryteriów w zakresie współczynnika tarcia.

Autorzy obecnie kontynuują badania terenowe mające na celu wzbogacenie istniejącej bazy wyników. Efekty prowadzonych prac w tym zakresie będą stanowić podstawę do kolejnych opracowań związanych z tematyką tekstury nawierzchni lotniskowych.

\section{Literatura}

1. Advisory Circular no: 150/5320-12C, U.S. Department of Transportation, Federal Aviation Administration (FAA) 1997 z późn. zm.

2. Contractor's Final Report for NCHRP Project 01-43, Guide for Pavement Friction, National Cooperative Highway Research Program, USA, February 2009.

3. Doc. 9157 ICAO AN/901 Aerodrome Design Manual Part 1 - Runways, ICAO, edycja trzecia, 2006.

4. Doc. 9137 ICAO AN/898 Airport Service Manual Part 2 - Pavement Surface Conditions, ICAO, edycja czwarta, 2002.

5. NO-17-A501:2015 Nawierzchnie lotniskowe. Badanie szorstkości.

6. PN-EN 13036-1:2010 Cechy powierzchniowe nawierzchni drogowych i lotniskowych. Metody badań. Część 1: Pomiar głębokości makrotekstury metodą objętościową.

7. PN-EN ISO 13473-1:2005 Charakterystyka struktury nawierzchni przy użyciu profili powierzchniowych. Część 1: Określenie średniego profilu głębokości.

8. Ueckermann A., Wang D., Oeser M., Steinauer B.: Calculation of skid resistance from texture, Journal of Traffic and Transportation Engineering, 2/2015.

9. Wasilewska M., Gardziejczyk W., Gierasimiuk P.: Ocena właściwości przeciwpoślizgowych nawierzchni betonowych $\mathrm{z}$ odkrytym kruszywem w początkowym okresie ich użytkowania, Roads and Bridges - Drogi i Mosty, nr 16, 2017.

10. Wesołowski M., Iwanowski P.: Interpretacja właściwości przeciwpoślizgowych nawierzchni drogowych i lotniskowych na podstawie pomiaru współczynnika tarcia, Autobusy: technika, eksploatacja, systemy transportowe, 12/2017.

11. Wytyczne nr 2 Prezesa Urzędu Lotnictwa Cywilnego z dnia 25 stycznia 2016 r. w sprawie metod oceny, pomiaru oraz raportowania stanu nawierzchni drogi startowej, 2016.

12. Załącznik do Decyzji Dyrektora Wykonawczego EASA nr 2017/021/R z dnia 08 grudnia 2017 r. wdrażającej wydanie czwarte Specyfikacji Certyfikacyjnych (CS) oraz Materiałów Zawierających Wytyczne (GM) do Projektowania Lotnisk CS-ADR-DSN, 2017.

13. Załącznik 14 ICAO do Konwencji o Międzynarodowym Lotnictwie Cywilnym, Lotniska Tom I - Projektowanie i eksploatacja lotnisk, wydanie 6, 2013. 